Anne Miu Han Chan MBBS FHKCA

Kwok Fu Jacobus Ng MBCHB FANZCA

FHKAM(ANESTH)

Edwin Wai Nung Tong MBBS FANZCA

FHKAM(ANESTH)

Gordon Siu Kei Jan MBBS

\section{Control of shivering} under regional anesthesia in obstetric patients with tramadol

Purpose: Tramadol in a dose of $\mathrm{I} \mathrm{mg}^{-1}$ iv is effective in the treatment of shivering after general anesthesia. The current study aimed to investigate ( 1 ) whether tramadol was equally effective for shivering under regional anesthesia in obstetric patients and (2) whether effective treatment could be achieved with lower doses.

Methods: In a randomised, double-blind study, 36 obstetric patients who shivered during Cesarean section under regional anesthesia and who requested anti-shivering treatment were allocated to one of three groups for iv treatment: Group T0.5 received tramadol $0.5 \mathrm{mg} \cdot \mathrm{kg}^{-1}(n=12)$, Group T0.25 tramadol $0.25 \mathrm{mg} \cdot \mathrm{kg}^{-1}(n=13)$ and Group NS normal saline $0.05 \mathrm{ml} \cdot \mathrm{kg}^{-1}(n=1 \mathrm{I})$. Treatment efficacy was evaluated subjectively by the parturient as no improvement, slight improvement, or marked improvement. The attending anesthesiologist who was blinded also independently noted the time elapsed from treatment to the time shivering subsided. Side effects such as nausea, vomiting or sedation and Apgar scores of the newborn were also noted.

Results: Eighty percent of parturients in Group T0.5 and $92 \%$ in Group T0.25 were judged by observers to have shivering controlled compared with $27 \%$ in Group NS $(P<0.001)$. The response rates of Group T0.5 and Group T0.25 were not different. There was no increased incidence of side effects in the treatment groups.

Conclusion: We conclude that tramadol iv was effective in the treatment of intraoperative shivering during regional anesthesia for Cesarean section. There was no demonstrable difference in response rate or incidence of side effects between the two doses of $0.5 \mathrm{mg} \cdot \mathrm{kg}^{-1}$ and $0.25 \mathrm{mg} \cdot \mathrm{kg}^{-1}$.

Objectif : Le tramadol en dose de I $\mathrm{mg} \cdot \mathrm{kg}^{-1}$ iv est efficace pour le traitement des frissons après l'anesthésie générale. La présente étude veut analyser (1) si le tramadol est également efficace contre les frissons sous anesthésie obstétricale régionale et (2) si le traitement efficace peut se faire avec de plus faibles doses.

Méthode :Dans une étude randomisée et à double insu, 36 parturientes atteintes de frissons pendant la césarienne sous anesthésie régionale ont été réparties en trois groupes pour recevoir un traitement de tramadol iv : le Groupe T0,5 en a reçu $0,5 \mathrm{mg}^{\mathrm{kg}-1}(n=12)$, le Groupe T0,25 en a reçu 0,25 $\mathrm{mg}^{-1} \mathrm{~kg}^{-1}(n=13)$ et le Groupe $\mathrm{SN}$ a eu $0,05 \mathrm{ml} \cdot \mathrm{kg}^{-1}$ de solution saline normale $(n=1 \mathrm{I})$. L'efficacité du traitement a été évaluée subjectivement par les parturientes : aucune amélioration, légère amélioration ou importante amélioration. De son côté, l'anesthésiologiste traitant, observateur impartial, a noté le temps écoulé entre le traitement et la fin des frissons. On a aussi enregistré les effets secondaires comme les nausées, les vomissements ou la sédation et les indices d'Apgar du nouveau-né.

Résultats : Quatre-vingt pour cent des parturientes du Groupe T0,5 et $92 \%$ de celles du Groupe T0,25 ont bénéficié du traitement des frissons selon les observateurs, mais $27 \%$ seulement des patientes du Groupe SN $(P<0,00 I)$. Le temps de réaction des groupes T0,5 et T0,25 n'étaient pas différents. II n'y a pas eu d'incidence accrue d'effets secondaires dans les groupes traités.

Conclusion : Nous pouvons conclure que le tramadol iv a été efficace pour le traitement des frissons peropératoires pendant une césarienne sous anesthésie régionale. Il n'y a pas eu de différence démontrable de temps de réaction ou d'incidence d'effets secondaires selon les deux doses de $0,5 \mathrm{mg} \cdot \mathrm{kg}^{-1}$ et de $0,25 \mathrm{mg} \cdot \mathrm{kg}^{-1}$.

From the Department of Anaesthesiology, the University of Hongkong and the Department of Anaesthesiology, Queen Mary Hospital , Hongkong.

Address correspondence to: Dr Kwok Fu Jacobus Ng, Department of Anaesthesiology, The University of Hongkong, Room 424, Block K,

Queen Mary Hospital, Hongkong, PR China. Phone: 852-28553303; Fax: 852-28551654; E-mail: jkfng@hkucc.hku.hk.

Accepted for publication December 13, 1998 
$\mathrm{R}$ EGIONAL anesthesia (extradural/subarachnoid) is a safe and popular anesthetic technique for Cesarean section, both in elective and emergency situations. One of the common complications of this technique is shivering, with an incidence of $39 \%$ in our institution. ${ }^{1}$ Shivering causes distress to the patient. It may also increase metabolic rate by up to $400 \%$, induce arterial hypoxemia and lactic acidosis, increase intraocular pressure and cause artefacts in monitors. ${ }^{2-6}$

Among the pharmacological methods of controlling shivering, meperidine has been shown to be effective, ${ }^{7,8}$ with a minimum effective dose of $\mathbf{0 . 3 5}$ $\mathrm{mg} \cdot \mathrm{kg}^{-1} \cdot{ }^{8}$

Tramadol has been used as an analgesic for labour pain without adversely affecting the mother or newborn. ${ }^{9}$ In addition, in a dose of $1 \mathrm{mg} \cdot \mathrm{kg}^{-1}$ iv, has been shown to be effective in the treatment of post-operative shivering. ${ }^{10,11}$ With its pharmacodynamic advantage in causing less respiratory depression and sedation, ${ }^{12,13}$ and its unique status of not being a controlled drug, it has potential use in the control of shivering in the obstetric suite because it is more convenient and, theoretically, safer than meperidine. Tramadol and meperidine are approximately equipotent $^{14}$ with respect to analgesia. Although the antishivering and analgesic effects of these two agents may be mediated via different receptors, we postulate that tramadol may control shivering at doses $<1 \mathrm{mg} \cdot \mathrm{kg}^{-1}$.

The aim of the present study was to investigate the safety and efficacy of intravenous tramadol in controlling shivering in obstetric patients under regional anesthesia for Cesarean section and to determine the optimal dose of tramadol to achieve a therapeutic effect with minimal side effect.

\section{Methods}

The study was approved by the ethics committee of the University of Hong Kong. All parturients included gave voluntary, written informed consent to participate in the study before anesthesia. Only ASA I and II consenting parturients who subsequently developed shivering intra-operatively during elective or emergency Cesarean section under regional (subarachnoid or extradural) anesthesia and who requested treatment for shivering were studied.

Patients with known hypersensitivity to tramadol, with initial body temperature $>38.0^{\circ} \mathrm{C}$ or $<36.5^{\circ} \mathrm{C}$, with a known history of alcohol or substance abuse, or who received intramuscular meperidine for labour pain within one hour were excluded.

Subarachnoid or extradural anesthesia was instituted at either $\mathrm{L}_{2-3}, \mathrm{~L}_{3-4}$ or $\mathrm{L}_{4-5}$ interspace. Bupivacaine
$0.5 \%$ was used in all cases. The volume of preloading intravenous fluid, the use of ephedrine for hypotension, and the dose of local anesthetic and opioid were determined by the attending anesthesiologists' and were not affected by inclusion in the study. All preloading fluids and drugs were to be given at room temperature. The operating room temperature was kept at $24^{\circ} \mathrm{C}$. A standard double layered blanket was used to cover the chest and upper limbs of all patients. Standard monitoring of non-invasive blood pressure, ECG and pulse oximeter were used.

Patients eligible for study were randomly allocated to one of three groups: Group T0.5 received 0.5 $\mathrm{mg} \cdot \mathrm{kg}^{-1}$ tramadol; Group T0.25 received 0.25 $\mathrm{mg} \cdot \mathrm{kg}^{-1}$ tramadol and Group NS received 0.05 $\mathrm{ml} \cdot \mathrm{kg}^{-1}$ normal saline. All drugs were given as an ip bolus. Anesthesiologists and patients were blinded to the treatment. Randomisation and blindness of the study were assured by a strict protocol. Before start of the operation, three syringes containing $5 \mathrm{ml}$ solution each were prepared by the anesthesiologist involved. The first syringe contained tramadol $10 \mathrm{mg} \cdot \mathrm{ml}^{-1}$, the second tramadol $5 \mathrm{mg} \cdot \mathrm{ml}^{-1}$ and the third normal saline. These syringes were labeled 1,2 or 3 and put into a box with three compartments. Should the parturient develop shivering and require treatment, an anesthetic assistant not involved in any other way in the study would pick randomly from a set of sealed envelops and pick out one of the three syringes as instructed in the envelop. The label on the syringe was removed before handling it to the anesthesiologist and kept by the assistant until the end of the operation. The assistant was instructed not to disclose the label to the anesthesiologist, who then gave the injection at a dose of $0.05 \mathrm{ml} \cdot \mathrm{kg}^{-1}$.

The anti-shivering effect was assessed both by the parturient and by the observing anesthesiologist. The parturient was asked to evaluate, five minutes after injection the effect of the treatment as either no improvement, slight improvement, or marked improvement. The attending anesthesiologist independently recorded the time that he or she subjectively assessed the shivering to have subsided. If shivering did not subside after $15 \mathrm{~min}$, the treatment was considered not effective. Recurrence of shivering, if any, was also recorded until the parturient left the operating theatre suite.

The attending anesthesiologist also assessed the degree of sedation at 5 and $10 \mathrm{~min}$ on a three point scale where $0=$ no sedation; $I=$ mildly sedated, easily rousable and II = heavily sedated. The parturient was also asked specifically for feelings of nausea or dizziness or other discomfort and observed for vomiting. 


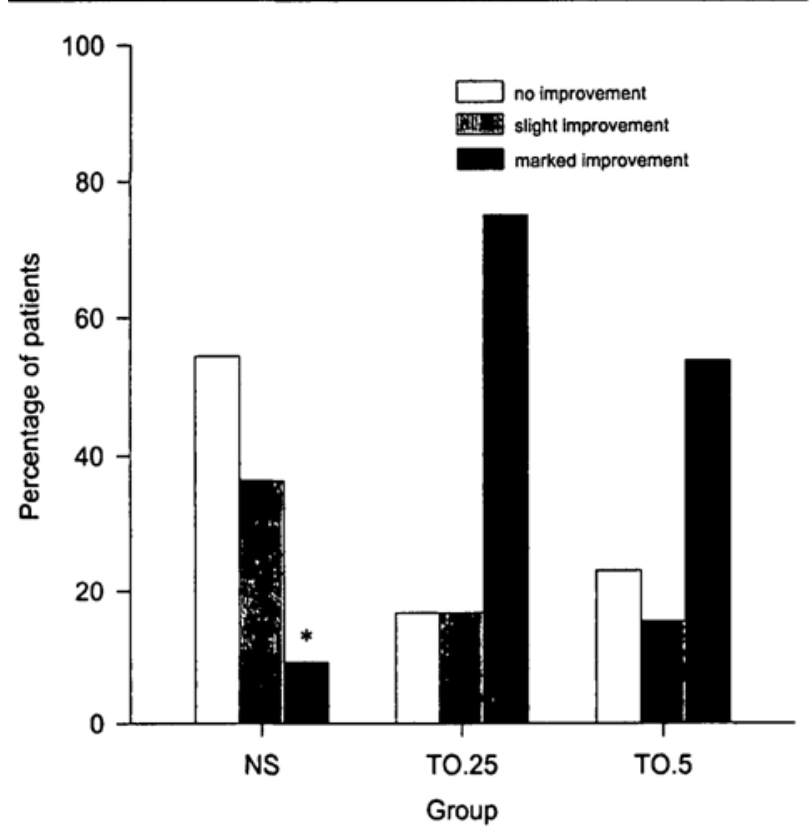

FIGURE I Paturient assessment of anti-shivering effect. Only one parturient in placebo group reported marked improvement ( ${ }^{*} P=0.016$, Kruskal-Wallis $A N O V A$ ).

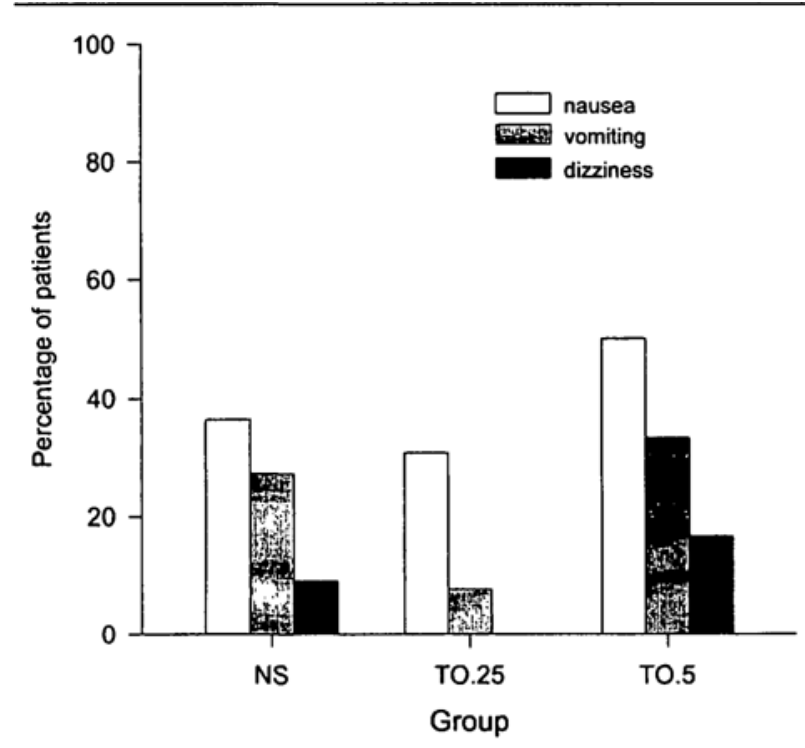

FIGURE 2 Incidence of side effects in different groups. (P. NS).

The $\mathrm{BP}$, pulse and $\mathrm{SpO}_{2}$ were recorded every five minutes for $15 \mathrm{~min}$. Apgar scores at one and five minutes and cord blood $\mathrm{pH}$ were recorded if the study drug was given before delivery. The parturient's body temperature before the start of operation and the OR
TABLE I Patient demographics

\begin{tabular}{lllll}
\hline & $\begin{array}{l}\text { Grous } \text { T0.5 } \\
(n=12)\end{array}$ & $\begin{array}{l}\text { Group T0.25 } \\
(n=13)\end{array}$ & $\begin{array}{l}\text { Group NS } \\
(n=11)\end{array}$ \\
\hline Age & $30.3 \pm 3.58$ & $33.1 \pm 4.23$ & $32.2 \pm 5.10$ \\
ASA $^{*}$ & I & $10(83.3)$ & $9(69.2)$ & $9(81.8)$ \\
& II & $2(16.7)$ & $4(30.8)$ & $2(18.2)$ \\
Body weight $(\mathrm{kg})$ & $67.1 \pm 8.87$ & $73.1 \pm 10.4$ & $64.7 \pm 8.92$ \\
Body temperature $\left({ }^{\circ} \mathrm{C}\right)$ & $36.9 \pm 0.5$ & $37.2 \pm 0.3$ & $37.5 \pm 0.3$ \\
\hline
\end{tabular}

OR temperature $\left({ }^{\circ} \mathrm{C}\right)$ maintained at $24^{\circ} \mathrm{C}$.

Values are mean (SD)

* Number (percent)

TABLE II Anaesthetic details

\begin{tabular}{|c|c|c|c|}
\hline & $\begin{array}{l}\text { Group T0.5 } \\
(n=12)\end{array}$ & $\begin{array}{l}\text { Group T0.25 } \\
(n=13)\end{array}$ & $\begin{array}{l}\text { Group NS } \\
(n=11)\end{array}$ \\
\hline Technique extradural & $9(75.0)$ & $2(15.4)$ & $4(36.4)$ \\
\hline noid & $3(25.0)$ & $11(84.6)$ & $7(63.6)$ \\
\hline Highest dermatome $>\mathrm{T} 4$ & $4(33.3)$ & $3(23.1)$ & $1(9.09)$ \\
\hline T4 & $3(25.0)$ & $8(61.5)$ & $6(54.5)$ \\
\hline$<\mathrm{T} 4$ & $5(41.7)$ & $2(15.4)$ & $3(36.4)$ \\
\hline e dose extradural & $2.63 \pm 1.11$ & $2.5 \pm 0.00$ & $2.75 \pm 0.29$ \\
\hline subarachnoid & $0.25 \pm 0.00$ & $0.25 \pm 0.03$ & $0.25 \pm 0.03$ \\
\hline
\end{tabular}

Values are number (percent)

* mean $\pm \mathrm{SD}$

temperature were also recorded. If parturients developed nausea and vomiting after injection of the study drug, metoclopramide $10 \mathrm{mg} i v$ was administered.

\section{Statistics of power analysis}

The sample size of 12 in each group was able to detect a difference in response rate with $80 \%$ power at an error level of 0.05 , assuming a response rate of $60 \%$ in treatment group and $10 \%$ in placebo group.

Statistical analysis was performed using the software programme Statistica release 4.5 (StatSoft $^{\mathrm{TM}}$, Tulsa $^{\mathrm{TM}}$, Oklahoma, USA). Nonparametric data such as response rates, subjective improvement scores and Apgar scores were analysed by Kruskal-Wallis ANOVA. Mann-Whitney $U$ test or Chi-squared test was used if further pairwise comparison was necessary. Parametric data were compared by ANOVA followed by Tukey's HSD test if post-hoc pairwise comparison was necessary. Significance level was set at $P<0.05$.

\section{Results}

Thirty-nine parturients were studied. One parturient in Group T0.5 and two in Group NS were excluded because of incomplete data entry. Data from 36 parturients were used in the final analysis, 12 in Group T0.5, 13 in Group T0.25 and 11 in Group NS. 
TABLE III Apgar score of newborn in Group T0.5 and T0.25

\begin{tabular}{|c|c|c|c|c|c|c|}
\hline \multirow[b]{2}{*}{ Injection } & \multicolumn{3}{|c|}{ Group T0.5 } & \multicolumn{3}{|c|}{ Group T0.25 } \\
\hline & $\begin{array}{l}\text { before } \\
\text { delivery } \\
(n=4)\end{array}$ & $\begin{array}{l}\text { after } \\
\text { delivery } \\
(n=8)\end{array}$ & $P$ value & $\begin{array}{l}\text { before } \\
\text { delivery } \\
(n=6)\end{array}$ & $\begin{array}{l}\text { after } \\
\text { delivery } \\
(n=7)\end{array}$ & $\begin{array}{l}P \\
\text { value }\end{array}$ \\
\hline AS 1 & $8.50 \pm 1.29$ & $8.75 \pm 1.28$ & ns & $8.83 \pm 0.98$ & $8.33 \pm 0.58$ & ns \\
\hline $\begin{array}{l}\text { AS } 5 \\
\text { minimum }\end{array}$ & $9.75 \pm 0.50$ & $9.88 \pm 0.35$ & ns & $9.83 \pm 0.41$ & $9.33 \pm 0.58$ & ns \\
\hline $\begin{array}{l}\text { AS } 1 \\
\text { minimum }\end{array}$ & 7 & 6 & & 8 & 8 & \\
\hline AS 5 & 9 & 9 & & 9 & 9 & \\
\hline
\end{tabular}

AS 1 = Apgar score at 1 minute

AS 5 = Apgar score at 5 minute

ns = no significance

Values are mean $\pm S D$

Demographic data, including body temperature are summarised in Table I. Most patients received an extradural or subarachnoid bolus dose of morphine during the institution of the block. The anesthetic technique, the highest level of block, and the dose of morphine administered are summarised in Table II.

Ten patients $(83 \%)$ in Group T0.5, 12 patients (92\%) in Group T0.25 and only three patients $(27 \%)$ in Group NS were judged by the observing anesthesiologist to have shivering controlled after injection of the study drug $(P<0.001$, Kruskal-Wallis $A N O V A)$. Further pairwise comparison between Groups T0.5 and T0.25 showed no difference in the response rates. In addition, more patients in Groups T0.5 and T0.25 rated their injection as effective, compared with Group NS (Figure 1). Again there was no difference between Groups T0.5 and T0.25 in this aspect.

There was no difference in the incidence of side effects among the three study groups (Figure 2). Six patients $(50 \%)$ in Group T0.5, three patients $(23 \%)$ in Group T0.25 and two patients in Group NS (18\%) required metoclopramide during the operation, the differences were not statistically significant $(P=0.20$, Kruskal-Wallis $A N O V A$ ). Five patients (42\%) in Group T0.5, eight patients (62\%) in Group T0.25 and seven patients $(64 \%)$ in Group NS required ephedrine, the differences were again not significant $(P=0.50$, Kruskal-Wallis $A N O V A$ ). No patient in any group developed sedation or desaturation after injection of the study drug. There was also no difference in $\mathrm{BP}$ and $\mathrm{P}$ in the initial $15 \mathrm{~min}$ after injection. Only four patients in Group T0.5, six patients in Group T0.25 and one patient in Group NS received the study drug before delivery. The Apgar scores of newborns of these patients are presented in Table III.
In those patients who responded, the onset time was shorter in Group T0.5 (3.8 min, 95\% C.I. 2.3 $5.3 \mathrm{~min}$ ) and Group T0.25 (5.4 min, 95\% C.I. 3.7 $7.1 \mathrm{~min}$ ) than in Group NS ( $10.0 \mathrm{~min}, 95 \%$ C.I. 0.83 $-20.8 \mathrm{~min})(P<0.01$, ANOVA followed by Tukey HSD test). Four patients (40\%) in Group T0.5 and seven patients (58\%) in Group T0.25. had recurrence of shivering after initial control $\left(P=\mathrm{NS}, \chi^{2}\right)$.

\section{Discussion}

The mechanism of shivering under regional anesthesia is not fully understood. Possible contributing factors are a decrease in core temperature and misinformation from receptors. A decrease in core temperature may be due to (1) sympathetic blockade which results in peripheral vasodilatation, increased cutaneous blood flow, and subsequent increased heat lost via skin, ${ }^{15,16}(2)$ a cold operating room, or the rapid infusion of crystalloid solutions at room temperature, ${ }^{17,18}$ or (3) the direct effects of cold anesthetic solutions upon thermosensitive structures within the spinal cord. As well, local anesthetics introduced into the extradural space might modify environmental thermal cues, with resultant inappropriate thermal responses to false information. Treatment modalities have included covering the patient with blankets, application of radiant heat and warming the operating room suite. ${ }^{15,17,19}$ The use of warm local anesthetic solution ${ }^{18,20}$ or warm intravenous fluids $^{20}$ has met with varying degrees of success. Addition of various opioids extradurally also reduced the incidence of shivering. ${ }^{21,22}$

Our study was designed to standardise these possible confounding factors while reflecting the usual practice in our institution. Operating room temperature was held constant at $24^{\circ} \mathrm{C}$, intravenous fluids and drugs were 
administered at room temperature and a double layer blanket was used for all parturients to cover the upper part of body. Body temperature was also recorded at the beginning of the operation. All patients received morphine either extradurally or subarachnoidly.

Tramadol is an analgesic with agonist properties on opioid receptors. Tramadol also activates the monoaminergic receptors of the descending spinal inhibitory pathway of pain. The main opioid effect of tramadol is mediated via the $\mu$-receptor, with minimal effect at $\kappa$-, or $\delta$ - binding sites. ${ }^{23}$ Tramadol also inhibits in vitro synaptosomal noradrenaline and serotonin uptake, which contributes to its analgesic effect. ${ }^{23}$

Our study demonstrated that tramadol, in a dose as low as $0.25 \mathrm{mg} \cdot \mathrm{kg}^{-1}$ successfully controlled shivering in parturients undergoing Cesarean section under regional anesthesia. We could not demonstrate any difference in response between $0.5 \mathrm{mg} \cdot \mathrm{kg}^{-1}$ and 0.25 $\mathrm{mg} \cdot \mathrm{kg}^{-1}$ tramadol. Previous studies have used 1 $\mathrm{mg} \cdot \mathrm{kg}^{-1}$ tramadol to control shivering. ${ }^{10,11}$ We investigated $1 \mathrm{mg} \cdot \mathrm{kg}^{-1}$ tramadol in a pilot study and the incidence of nausea and vomiting at this dose was unacceptably high. Considering the minimum effective dose of meperidine in controlling shivering and the equipotency of tramadol and meperidine with respect to analgesia, ${ }^{14}$ we modified our dosage regimen to $0.5 \mathrm{mg} \cdot \mathrm{kg}^{-1}$ and $0.25 \mathrm{mg} \cdot \mathrm{kg}^{-1}$ tramadol and normal saline. From the current study, the administration of $0.25 \mathrm{mg} \cdot \mathrm{kg}^{-1}$ and $0.5 \mathrm{mg} \cdot \mathrm{kg}^{-1}$ tramadol iv did not result in higher incidence of side effects compared with normal saline.

Based on our study it was not possible to draw conclusions about the mechanisms involved in the antishivering effect of tramadol. For meperidine, the effect is most likely mediated via receptors other than the $\mu$-receptor, in particular the $\kappa$-receptor. This is supported by observations that meperidine controlled shivering better than morphine and fentanyl, and that the anti-shivering effect of meperidine was not reversed by low dose, but by high dose naloxone. ${ }^{24,25}$ Tramadol has minimal $\kappa$-receptor activity. ${ }^{23}$ The $\mu$ receptor activity of tramadol was also unlikely to be important in the effect we observed. Pure $\mu$-agonists such as morphine and fentanyl do not have significant anti-shivering effect. ${ }^{24}$ Thus, it is highly likely that the anti-shivering effect of tramadol was mediated via its serotonergic or noradrenergic activity or both.

Our study did not control tightly the various factors which might influence the incidence of shivering, such as the dose of subarachnoid or extradural morphine or the temperature of drugs and intravenous fluids. However, this should not have affected the validity of our comparisons. First, the current study focused on the response after treatment, rather than the incidence of shivering. Second, by randomisation, the three study groups had been subjected to a similar degree of influence of these factors. However, there was an inequality of anesthetic techniques in the two study groups despite randomisation, with more extradurals in Group T0.5 and more subarachnoids in Group T0.25. We thought this was also unlikely to have affected our comparison as it has been shown that vasoconstriction, shivering thresholds and thermoregulatory processing are very'similar during extradural and subarachnoid anesthesia. ${ }^{26}$

We have not performed a direct comparison between tramadol and meperidine. However, tramadol does have advantages over meperidine in that it is not a controlled drug and it causes less respiratory depression and sedation than other opioids at equivalent dosages. ${ }^{12,13}$ Patients receiving meperidine $i p$ for control of shivering during extradural anesthesia were more drowsy at two and five minutes after injection, although there was no difference in level of consciousness at later intervals. ${ }^{27}$ On the other hand, some paturients developed recurrence of shivering after initial control with tramadol. Further studies are indicated to compare these two agents directly to substantiate these possible differences. Synergism in the anti-shivering properties of these two agents is also possible, as their effects are likely mediated via different receptors. It might also be interesting to investigate the effect of repeating tramadol administration in various dosages should shivering recur.

We conclude that $0.25 \mathrm{mg} \cdot \mathrm{kg}^{-1}$ tramadol iv effectively controlled shivering during Cesarean section under regional anesthesia with minimal side effects. Increasing the tramadol dose to $0.5 \mathrm{mg} \cdot \mathrm{kg}^{-1}$ did not improve its therapeutic effect.

\section{Acknowledgments}

We would like to thank all anesthesiologists of the Department of Anaesthesiology, Queen Mary Hospital. We would also thank our colleagues in the Department of Obstetrics \& Gynecology and the Department of Paediatrics, as well as the nursing staff of Tsan Yuk Hospital for their kind cooperation and support. Finally, we would like to acknowledge the support from Boehringer Mannheim (Hongkong) for the supply of tramadol in this study.

\section{References}

1 Chan WS, Irwin MG, Tong WN, Lam YH. Prevention of hypotension during spinal anaesthesia for Caesarean section: ephedrine infusion versus fluid preload. Anaesthesia 1997; 52: 908-13. 
2 Guffin A, Girard D, Kaplan JA. Shivering following cardiac surgery: hemodynamic changes and reversal. J Cardiothorac Anesth 1987; 1: 24-8.

3 Mahajan RP, Grover VK, Sharma $S L$, Singh $H$. Intraocular pressure changes during muscular hyperactivity after general anesthesia. Anesthesiology 1987; 66: 419-21.

4 Bay J, Nunn JF, Prys-Roberts C. Factors influencing arterial $\mathrm{PO}_{2}$ during recovery from anaesthesia. $\mathrm{Br} \mathrm{J}$ Anaesth 1968; 40: 398-407.

5 Ciofolo MJ, Clergue F, Devilliers C, Ben Ammar M, Viars $P$. Changes in ventilation, oxygen uptake, and carbon dioxide output during recovery from isoflurane anesthesia. Anesthesiology 1989; 70: 737-41.

6 De Courcy JG. Artefactual "hypotension" from shivering (Letter). Anaesthesia 1989; 44: 787-8.

7 Liem ST. Aldrete JA. Control of post-anaesthetic shivering. Can Anaesth Soc J 1974; 21: 506-10.

8 Wrench IJ, Singh P, Dennis AR, Mabajan RP, Crossley $A W$. The minimum effective doses of pethidine and doxapram in the treatment of post-anaesthetic shivering. Anaesthesia 1997; 52: 32-6.

9 Viegas $O A C$, Khaw B, Ratnam SS. Tramadol in labour pain in primiparous patients. A prospective comparative clinical trial. Eur J Obstet Gynecol Reprod Biol 1993; 49: 131-5.

10 Pausawasdi S, Jirasiritbum S, Pbanarai C. The use of tramadol hydrochloride in the treatment of post-anesthetic shivering. J Med Assoc Thai 1990; 73: 16-20.

11 Svetlov VA, Kozlov SP, Sarkisova NG, Vashchinskaya TV. Shivering and rigor during the awakening period. Anesteziol Reanimatol 1994; Nov-Dec: 12-6.

12 Vickers $M D$, Paravicini D. Comparison of tramadol with morphine for post-operative pain following abdominal surgery. Eur J Anaesthesiol 1995; 12: 265-71.

13 Houmes R-JM, Voets $M A$, Verkaaik A, Erdmann W, Lachmann $B$. Efficacy and safety of tramadol versus morphine for moderate and severe postoperative pain with special regard to respiratory depression. Anesth Analg 1992; 74: 510-4.

14 Lee CR, McTavish D, Sorkin EM. Tramadol. A preliminary review of its pharmacodynamic and pharmacokinetic properties, and therapeutic potential in acute and chronic pain states. Drugs 1993; 46: 313-40.

15 Waters $H R$, Rosen $N$, Perkins $D H$. Extradural blockade with bupivacaine. A double blind trial of bupivacaine with adrenaline $1 / 200,000$ and bupivacaine plain. Anaesthesia 1970; 25: 184-90.

16 Chamberlain DP, Chamberlain BDL. Changes in the skin temperature of the trunk and their relationship to sympathetic blockade during spinal anesthesia. Anesthesiology 1986; 65: 139-43.
17 Pflug AE, Aasheim GM, Foster C, Martin RW. Prevention of post-anaesthesia shivering. Can Anaesth Soc J 1978; 25: 43-9.

18 Walmsley AJ, Giesecke AH, Lipton JM. Contribution of extradural temperature to shivering during extradural anaesthesia. Br J Anaesth 1986; 58: 1130-4.

19 Sharkey $A$, Lipton JM, Murphy MT, Giesecke AH. Inhibition of postanesthetic shivering with radiant heat. Anesthesiology 1987; 66: 249-52.

20 Webb PJ, James FM III, Wheeler AS. Shivering during epidural analgesia in women in labor. Anesthesiology $1981 ; 55: 706-7$.

21 Liu WHD, Luxton MC. The effect of prophylactic fentanyl on shivering in elective Caesarean section under epidural analgesia. Anaesthesia $1991 ; 46: 344-8$.

22 Sutberland J, Seaton $H$, Lowry C. The influence of epidural pethidine on shivering during lower segment Caesarean section under epidural anaesthesia. Anaesth Intensive Care 1991; 19: 228-32.

23 Raffa RB, Friderichs E, Reimann W, Shank RP, Codd $E E$, Vaught $J L$. Opioid and nonopioid components independently contribute to the mechanism of action of tramadol, an 'atypical' opioid analgesic. J Pharmacol Exp Ther 1992; 260: 275-85.

24 Pauca AL, Savage RT, Simpson S, Roy RC. Effect of pethidine, fentanyl and morphine on post-operative shivering in man. Acta Anaesthesiol Scand 1984, 28 : 138-43.

25 Kurz M, Belani KG, Sessler DI, et al. Naloxone, meperidine and shivering. Anesthesiology 1993; 79: 1193-201.

26 Ozaki $M$, Kurz $A$, Sessler DI, et al. Thermoregulatory thresholds during epidural and spinal anesthesia. Anesthesiology 1994; 81: 282-8.

27 Casey WF, Smith CE, Katz JM, O'Loughlin K, Weeks $S K$. Intravenous meperidine for control of shivering during Caesarean section under epidural anaesthesia. Can J Anaesth 1988; 35: 128-33. 